\title{
Factors Influencing Development of Crypto- gamic Soil Crusts in Utah Deserts
}

\author{
DAVID C. ANDERSON, KIMBALL T. HARPER, AND RALPH C. HOLMGREN
}

\begin{abstract}
The relation of some physical and chemical soil characteristics to cryptogamic crust development was determined from sites in semidesert regions of southern Utah. The effects of grazing on cryptogamic crust development also was examined. Electrical conductivity, percentage silt, and soil phosphorus were found to be correlated with well-developed cryptogamic crusts. Both total cryptogamic cover and the number of cryptogamic species decreased under grazing pressure. The management of rangelands, especially in arid regions, would be strengthened by understanding the role of cryptogamic crusts and considering them in range management decisions.
\end{abstract}

The vascular plants of many semidesert areas furnish a scant ground cover of discrete and widely spaced units. Between the plants are rather extensive open spaces exposed to the elements. Where soils are gravelly, a pavement of pebbles provides protection from erosive forces of wind and water. Another factor, less obvious but of importance in the control of erosion in the interspaces, particularly where the gravel pavement is weak or absent, is a community of nonvascular or cryptogamic plants that grow upon or immediately beneath the soil surface. Where well established and undisturbed by trampling, the cryptogams form a recognizable crust (Fig. 1).

Algae are the primary components of these crusts, but in some environments, the more visible macroscopic lichens and mosses are common members of the cryptogamic cover (Anderson and Rushforth 1977, Kleiner and Harper 1972). Even though they are small and often inconspicuous, cryptogamic species play an important role in soil stabilization in semideserts (Fletcher and Martin 1942). Algal filaments, fungal mycelia, and tissues of lichens and mosses are present throughout the surface few millimeters of many semidesert soils (Anderson and Rushforth 1977, Hunt and Durrell 1966). Where lichens and mosses grow in abundance, the stability of the soil surface is readily apparent, but the less obvious algae, especially the filamentous algae, are probably more effective in binding the surface soil particles (Anantani and Marathe 1974; Durrell and Shields 1961). The thick gelatinous sheaths that encase some of the algal species probably add strength and toughness to the felt-like web of filaments among the soil particles in the surface 1 or 2 millimeters of a well-established algal crust.

Cryptogamic crusts are common in the arid regions of the westèrn United States. Well-developed crusts occur throughout the

Authors are, respectively, senior staff ecologist, Native Plants, Inc., Salt Lake City, Utah 84 108; professor, botany and range science, Brigham Young University, Provo, Utah 84602; and range scientists, Intermountain Forest and Range Experiment Station, U.S. Forest Service, Provo, Utah 84601.
Great Basin Desert, the semideserts of the Colorado Plateau, and in many pinyon-juniper communities of Utah, Nevada, Arizona, Colorado, New Mexico, and Wyoming (Fig. 2). Biological crusts are conspicuous on the gypsiferous soils of central and southern Utah, southern Nevada, and northern Arizona (Fig. 3). Research focusing on soil crusts and surface cryptogams has been done on many of the areas mentioned (Shields and Durrell 1964, Fletcher and Martin 1942, Loope and Gifford 1972, Rychert and Skujins 1974). Taxonomic and nitrogen fixation studies dominate the literature dealing with biologically induced soil crusts. The role of cryptogamic soils crusts in nitrogen fixation is well documented (Henriksson and Simu 1971, MacGregor and Johnson 1971, Reddy and Gibbons 1974, Rychert and Skujins 1974, Shields et al. 1957, Snyder and Wullstein 1973).

Some studies have been done on the physical role of biological crusts in semidesert ecosystems, but much is yet to be learned. Work by Loope and Gifford (1972) dealt with the effect of soil crusts on infiltration and sedimentation. Biologically crusted soils were found to increase infiltration of water and to decrease sediment in the runoff. Kleiner and Harper (1972) in their analysis of two grassland communities in Canyonlands National Park suggested that in the absence of excessive grazing, lichens, and mosses

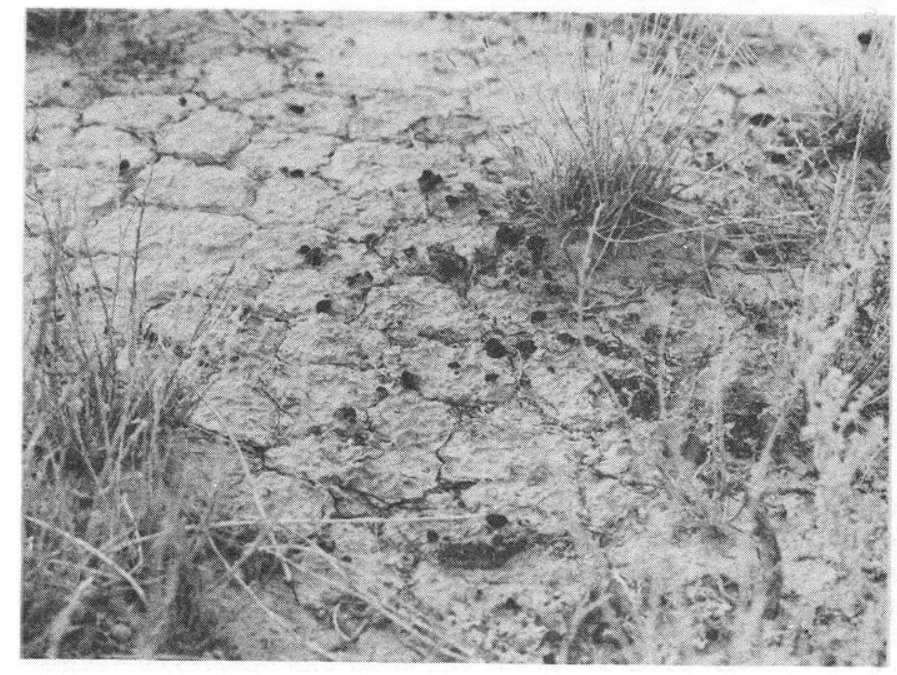

Fig. 1. Cryptogamic soil crust at DER is typified by lichens (dark structures) and algae indicated by the wrinkled soil surface. 


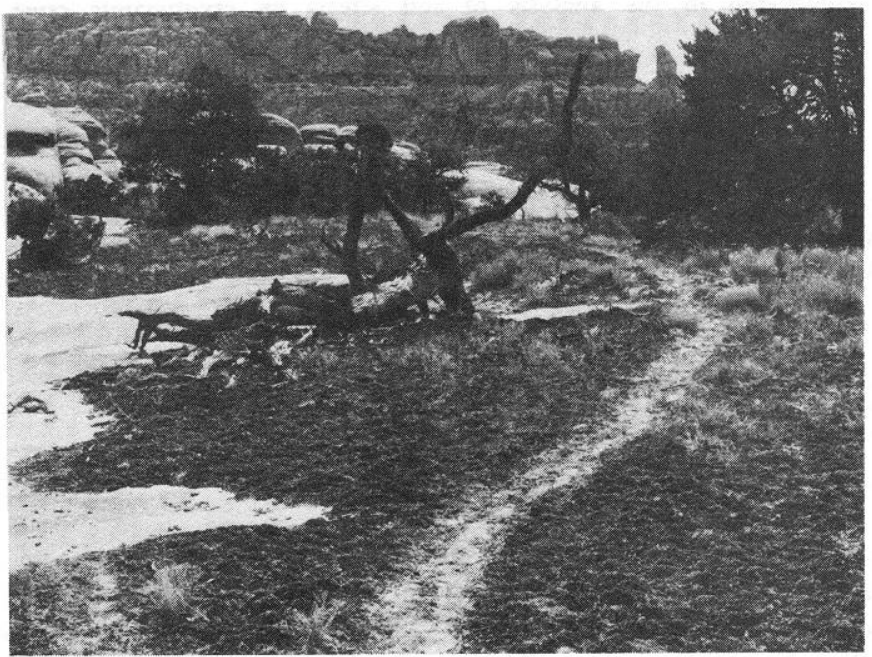

Fig. 2. Soil cryptogamic crust in Virginia Park, Canyonland National Park. The dark cast to the soil is due to the abundance of mosses and lichens.

tend to stabilize the sandy, erodable soil, adding to the long-term stability of desert grasslands. Ali and Sandhu (1972) proposed using blue-green algae as primary colonizers to stabilize highly saline soils. Such a process was used in reclaiming alkaline Usar lands in northern India (Singh 1950).

Studies by Looman (1964) on the ecology of lichen and bryophyte communities in Saskatchewan yielded two important points: cryptogams are useful as differential species in the classification of grasslands; and more importantly, lichen-free grasslands could be maintained through continous moderate to heavy grazing, suggesting cryptogams can be used to evaluate grassland management practices. Little has been done to incorporate the information known about soil crusts into range management considerations. It seems likely that our ability to manage ranges, especially in arid regions, would be strengthened by such an inclusion.

The purposes of this study are two-fold: first, we seek to determine the relations of some physical and chemical soil factors to crust development, and second, we desire to evaluate the effect of grazing on cryptogamic soils crusts.

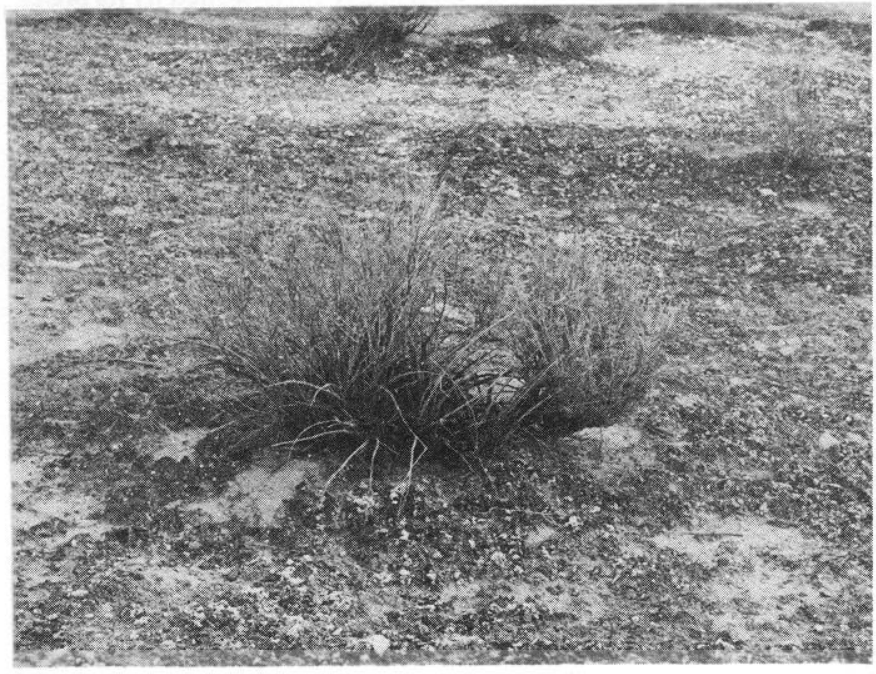

Fig. 3. The crust at Hurricane and St. George is predominately a lichen crust with intermingling mosses. This highly developed cryptogamic crust is associated with gypsiferous soils.

\section{Study Areas}

Five areas in the southern part of Utah were selected for study (Fig. 4). All are characterized by low precipitation, hot summers, and cold winters. The Desert Experimental Range (DER) of the USDA-Forest Service is located in western Utah and is the driest of all the areas considered: precipitation averages $15 \mathrm{~cm}$ annually. Two study areas are along the Hurricane Fault in extreme southwestern Utah near St. George and Hurricane, which receive about 19 and $22 \mathrm{~cm}$ average annual precipitation, respectively. Virginia Park in Canyonlands National Park in southeastern Utah is the wettest site, receiving about $30 \mathrm{~cm}$ of annual precipitation, mainly during the warm season. The temperature extremes for all five areas are similar over the past 10 years. Maximums are around $40^{\circ} \mathrm{C}$ and minimums $-14^{\circ} \mathrm{C}$ or lower (Holmgren 1973).

Quite different vascular communities prevail at the study sites. Species of low shrubs typical of the cold desert dominate the stands at the DER. Hilaria (galleta) and Bouteloua (blue grama) are the most common grasses. Ephedra (Mormon tea) and Larrea (creosotebush) are the most common vascular plants at St. George, while Ephedra and Petalonyx (sandpaper plant) are the dominant vascular species at Hurricane. Hilaria and Stipa (needlegrass) grasslands characterize Virginia Park. An additional collection was made north of Black Rock, Utah, in Atriplex (saltbush) and Chrysothamnus (rabbitbrush) communities. The St. George and Hurricane study sites are on gypsum outcrops and have sparse vascular cover and heavy cryptogamic cover of algae, lichens, and intermingled mosses characteristic of gypsiferous soils.

\section{Methods}

To test for the effects of soil on development of cryptogamic crusts, 10 pairs of transects were sampled. Six pairs were located at the DER, one pair north of Black Rock, one pair south of St. George, another pair west of Hurricane, and the final pair in Virginia Park of Canyonlands National Park (Fig. 4). Members of each pair of transects were located within a few meters of each other and in an area of uniform topography and grazing use. Areas were selected, however, to show strong differences in degree of development of the cryptogamic crusts. Development of cryptogamic crust was described qualitatively in the field as light, moderate, or heavy. In some areas at DER, cryptogamic cover did not vary greatly between pairs of transects, but species diversity did appear to vary strongly. In these cases, the area with the more diverse flora was designated as having moderate cryptogamic crust

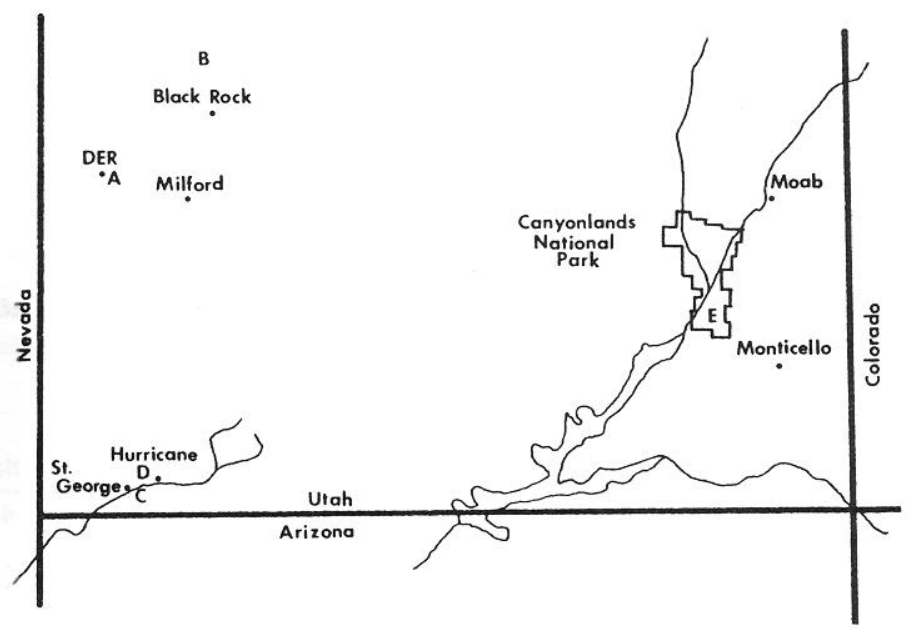

Fig. 4. Site locations: (A) Desert Experimental Range Station; (B) between Black Rock and Deseret; (C)east of St. George, near Bloomington;(D) 3 miles west of Hurricane; (E) Virginia Park in the Needles Section of Canyonlands National Park. 
development. Frequently, vascular plant cover of the transects of a pair differed suggesting edaphic causation.

Within each area, a starting point and direction for each transect was randomly selected. Fifteen quadrats, each $.5 \times .5\left(.25 \mathrm{~m}^{2}\right)$ were distributed along each transect at $2-\mathrm{m}$ intervals. Percentage cover of vascular and macroscopic nonvascular species was estimated ocularly using six cover classes, a method similar to that proposed by Daubenmire (1959, p. 43). Frequency of individual taxa was computed for the quadrats, and a list of vascular and cryptogamic species encountered along each transect was prepared. Vascular plant nomenclature follows Welsh and Moore (1973) throughout the report.

Along all transects, a subsample of the surface $2.5 \mathrm{~cm}$ of soil was taken at each quadrat location; the 15 subsamples were ultimately combined to provide a single composite transect sample for later laboratory analysis, which was done by the Soil Chemistry Laboratory of the Agronomy Department at Brigham Young University.

Electrical conductivity and $\mathrm{pH}$ were determined for 1:5 soil-towater mixtures. Cation exchange capacity was determined by standard procedures (Chapman 1965). Soil phosphorus was extracted with a solution of $0.2 \mathrm{~N}$ acetic acid. The extracted phosphorus was then determined by the method of Goldenberg and Fernandez (1966). Soil texture was determined by the hydrometer method (Day 1965).

The probability of a difference between variables occurring by chance for both grazing and soil effects is determined by a $t$-value based on a paired $t$-test (Steele and Torrie 1960).

Algal species at each transect were identified from a $25-\mathrm{cm}^{2}$ sample of the upper $\mathrm{cm}$ of the soil chosen as representative of the crust at that site. The sample was placed in a sterilized petri dish, moistened with modified Bristol's solution (Bischoff and Bold 1963 ) and cultured under continuous light at $20^{\circ} \mathrm{C}$ for two weeks. Slides for identifying diatoms were prepared from a soil culture following standard techniques (St. Clair and Rushforth 1977). A complete list of the algae, mosses, and lichens encountered by study site is given in Anderson and Rushforth (1977).

For the study of grazing effects, ten pairs of transects were established at the DER. Exclosures within pastures grazed in winter by sheep, or where fences between areas subject to different grazing treatments provide grazed-ungrazed or differential grazing contrasts. Transects were located in areas subjectively selected on opposite sides of fences having similar soils, vascular vegetation, and topography. Again, the starting point and direction of each transect were randomly selected. The grazing (or non-grazing) treatments had been in effect for over 40 years. Transects for this portion of the study were sampled exactly as for the soil influences portion.

\section{Results and Discussion}

\section{Soil Influences}

We attempted to identify soil parameters that favor development of crusts by subjectively selecting adjacent sites within a common grazing area that noticeably differ in respect to the degree of development of the crust. We found no significant difference in species diversity values for the vascular component of the vegeta-
Table 1. Summary and comparison of vegetative characteristics considered in the analysis of soil effects on cryptogamic crust development.

\begin{tabular}{|c|c|c|c|c|}
\hline \multirow[b]{2}{*}{ Crust development } & \multicolumn{2}{|c|}{$\%$ Cover } & \multicolumn{2}{|c|}{ No. Spp $/ 0.25 \mathrm{~m}^{2}$} \\
\hline & Vascular & $\begin{array}{l}\text { Lichen/ } \\
\text { Moss' }\end{array}$ & Vascular & $\begin{array}{l}\text { Lichen/ } \\
\text { Moss' } 1\end{array}$ \\
\hline Average light & 9.66 & 6.27 & 1.84 & 1.39 \\
\hline $\begin{array}{l}\text { Average moderate- } \\
\text { heavy } \\
t \text {-value (light versus }\end{array}$ & 12.24 & 20.92 & 1.94 & 3.38 \\
\hline moderate-heavy) & $-6.45 * * 2$ & $-2.12 * 3$ & $-.26^{\mathrm{ng}_{4}}$ & $3.74^{* *}$ \\
\hline
\end{tabular}

'Soil inhabiting lichens and mosses only.

2**Difference significant at .01 level.

3* Difference significant at .05 level.

${ }^{4}{ }^{\text {ns }}$ Difference not significant at .05 level.

tion between areas supporting poorly developed and areas supporting better developed cryptogamic crusts (Table 1). It should be noted that the dominant vascular plant species sometimes differed within pairs of transects. Since transect pairs were subjectively chosen because of apparent differences in the development of the cryptogamic community, the significant differences in cover and species diversity of the cryptogamic communities between members of the transect pairs is to be expected.

Several soil parameters differ significantly between areas of obviously different degrees of biological crust development (Table 2). Surface rock and percent sand are greater on areas having the less well developed crusts. Silt is a significantly more common soil constituent on sites with better developed crusts.

Table 3 shows the results of multiple regression analyses of the influence of selected edaphic characteristics on various characteristics of the cryptogamic crusts. For these analyses data were used from 18 transects considered for soil effects (no cover data were taken at the Blackrock site) and the 10 ungrazed transects used for the grazing effect. Rather than present formal regression equations, we report only those independent variables that make an important contribution to a given analysis and their partial contributions to the coefficient of multiple determination $\left(R^{2}\right)$ Each dependent variable (percent cover of cryptogamic crust, number of lichen and moss species per $0.25 \mathrm{~m}^{2}$, and number of algal species per transect) is analyzed in respect to five independent variables: $\mathrm{pH}$; electrical conductivity (salinity); extractable phosphorus; \% sand; and $\%$ silt. An $F$-value of 1.0 was arbitrarily selected as the minimum value for entrance of independent variables into the analysis. It should be noted that the partial contribution of a given independent variable to the total $R^{2}$ is strongly conditioned by its order of entry into the stepwise regression routine and associated independent variables.

Regression results show a high correlation between the combination of electrical conductivity, soil phosphorus, and $\mathrm{pH}$, and the degree of development of cryptogamic cover on soils. The coefficient of multiple determination of .78 suggests that about three fourths of the variation in cryptogamic cover could be accounted for by these three independent variables in this study. Less success

Table 2. Summary of soil characteristics considered in the analysis of soil effects on the development of cryptogamic crusts.

\begin{tabular}{|c|c|c|c|c|c|c|c|c|}
\hline Crust development & $\begin{array}{c}\text { Rock } \\
\text { cover }(\%)\end{array}$ & $\%$ sand & $\frac{\text { Soil texture }}{\% \text { silt }}$ & $\%$ clay & pH & $\begin{array}{l}\text { Cation } \\
\text { Exchange } \\
\text { Capacity } \\
(\text { meg/ } 100 \mathrm{~g})\end{array}$ & $\begin{array}{l}\mathrm{EC} \\
\text { (mmhos/cm) }\end{array}$ & $\begin{array}{c}\text { Extr. } \\
\text { p (ppm) }\end{array}$ \\
\hline Average light & 41.8 & 59.8 & 26.0 & 14.2 & 8.4 & 8.4 & .39 & 13.9 \\
\hline $\begin{array}{l}\text { Average moderate- } \\
\text { "heavy } \\
t \text {-value (light versus }\end{array}$ & 23.8 & 50.2 & 34.8 & 15.0 & 8.4 & 9.1 & .62 & 18.3 \\
\hline moderate-heavy) & $2.3 * 1$ & $3.16 * * 2$ & $-2.67 * * 1$ & $-.44^{\mathrm{ns}_{3}}$ & $.15^{\mathrm{ns} 3}$ & $-1.73^{n 8_{3}}$ & $-1.02^{n x_{3}}$ & $-3.86 * * 1$ \\
\hline
\end{tabular}

1**Difference significant at .01 level.

2* Difference significant at .05 level.

${ }^{\mathrm{nn}}$ Difference not significant at 05 level. 
Table 3. Results of stepwise multiple regression analyses of the influence of various soil characteristics on some characteristics of cryptogamic crusts in Utah deserts.

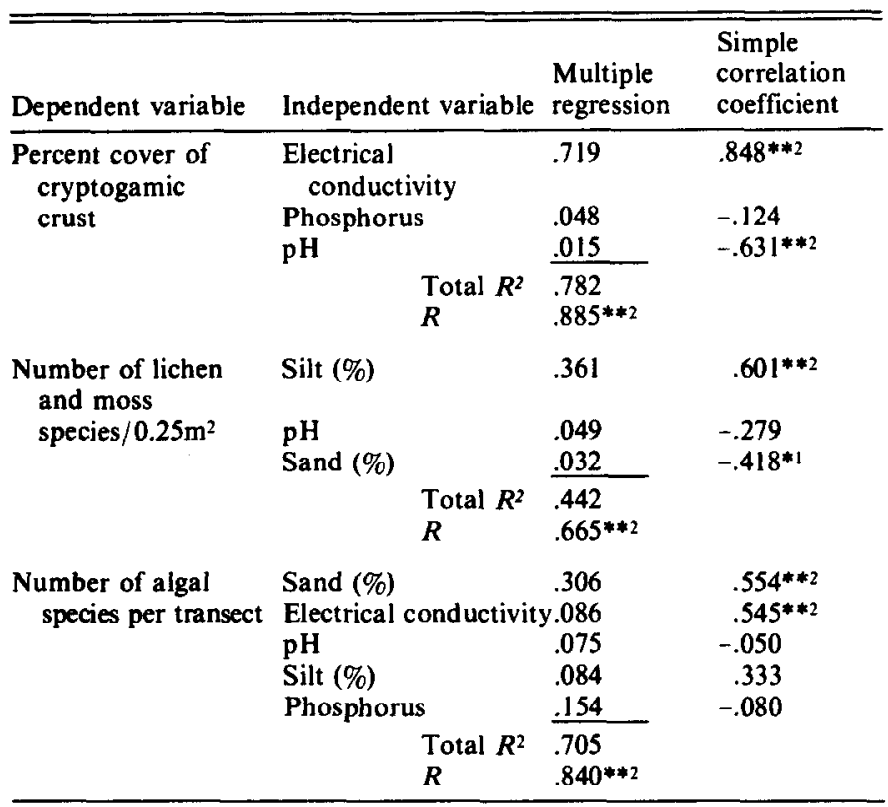

1* significant at the .05 probability level.

2** significant at the .01 probability level.

was experienced in attempts to predict the average number of lichen and/or moss species per quadrat and the number of algal species encountered per tansect. Coefficients of multiple determination were .44 and .71 , respectively, for those two relationships; the soil characteristics shown for these analyses account for a highly significant amount of the variation in the dependent variable, however. Soil texture and $\mathrm{pH}$ were the apparent influential variables controlling the number of lichen and moss species per quadrat. Soil texture was also strongly correlated to the number of alga species per transect. In both of these latter analyses, species diversity appears to increase as the finer particles of soil (silt and clay) increase; species diversity was negatively correlated with sand for both groups of organisms (i.e., lichens-plus-mosses and algae).

\section{Grazing Influence}

Observations made on both sides of fences that surround ungrazed exclosures or divide a reas of different grazing treatments at the DER illustrate the effect of hooved grazers on cryptogamic crusts. Grazing was by sheep at some time between late fall and early spring each year. The results from our sampling procedure fail to demonstrate a significant effect for either amount of cover or number of species per quadrat of the vascular plant community that can be attributed to grazing at the ten sites (Table 4). In

Table 4. Summary and comparison of vegetative characteristics considered in the analysis of grazing effects on persistence of cryptogamic crusts.

\begin{tabular}{|c|c|c|c|c|}
\hline \multirow[b]{2}{*}{ treatment } & \multicolumn{2}{|c|}{ Cover $(\%)$} & \multicolumn{2}{|c|}{ No. spp. $/ 0.25 \mathrm{~m}^{2}$} \\
\hline & Vascular & $\begin{array}{l}\text { Lichen/ } \\
\text { Moss' }\end{array}$ & Vascular & $\begin{array}{l}\text { Lichen/ } \\
\text { Mosses }\end{array}$ \\
\hline $\begin{array}{l}\text { Grazed } \\
\text { Ungrazed }\end{array}$ & $\begin{array}{l}12.3 \\
11.4\end{array}$ & $\begin{array}{r}.9 \\
4.1\end{array}$ & $\begin{array}{l}2.4 \\
2.1\end{array}$ & $\begin{array}{l}0.7 \\
2.8\end{array}$ \\
\hline $\begin{array}{l}\text { t-value (grazed } \\
\text { versus ungrazed) }\end{array}$ & $.79^{\mathrm{na} 2}$ & $-4.42 * * 3$ & $.90^{\mathrm{nx} 2}$ & $-6.11^{* * 3}$ \\
\hline
\end{tabular}

'Soil inhabiting lichens and mosses only.

$2^{\text {nes }}$ Difference not significant at .05 level.

3** Difference significant at .01 level.

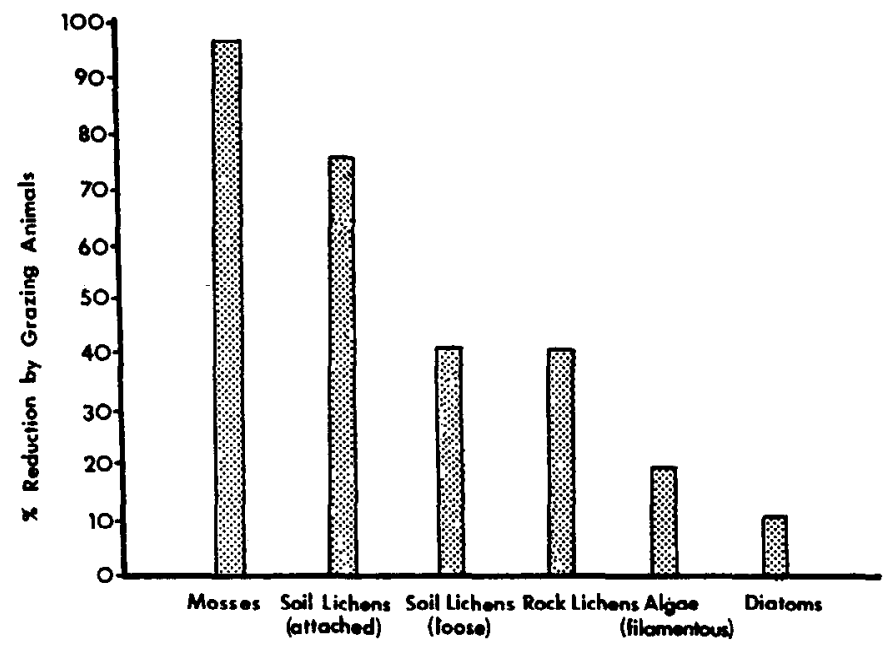

Fig. 5. The effect of grazing on six life form groups. Percent reduction of each group due to grazing is based on a commonness index.

contrast, the cryptogamic communities differ strongly in these characteristics between the paired areas. For the ten sample areas taken together, the grazed (or more heavily grazed) areas support only about $22 \%$ as much cover of lichen and mosses and $25 \%$ as many species of them per unit areas as the ungrazed exclosures.

Table 5 summarizes the soil characteristics used for the grazed and ungrazed transects. The analyses support our initial assumption that the abiotic environment was not significantly different across the fences selected for the grazing contrast studies. None of the eight variables considered differ significantly between the two treatments. Observed differences in the cryptogamic crust community thus seem attributable solely to use of the areas by livestock.

As shown in Table 6, the ungrazed (or lightly grazed) transects tend to support more total cryptogamic species per transect than their more heavily grazed mates (an average of 17.7 as compared to 14.9 species), but the differences occur primarily among the attached soil lichens and mosses, for which the differences are highly significant. The average number of filamentous algae, diatoms, rock lichens, and loose soil lichens detected on soils along any given transect were much the same or only slightly reduced for the ungrazed (or lightly grazed) and the more heavily grazed transects.

When total number of species per treatment is compared with number of species per transect, it is apparent that only a minor fraction of the desert cryptogams of the general area are present at a particular site. This points up the influence of factors of the site, primarily the soil characteistics, and in this regard, the response of cryptogams is essentially the same as that of the vascular plants.

\section{Conclusions}

The vigor of development of the cryptogamic crusts is closely correlated to soil chemistry and texture. Heavier textured soils having considerable salinity support the best developed crusts encountered in this study. No experimental evidence is available to indicate whether either soil texture or salinity exerts a causal influence on the vigor of the crust. It seems inevitable that heavy textured soils would retain more absorbed water in surface layers (and thus accessible to the cryptogams) than sandy soils because of the greater surface area of the soil particles. Hunt and Durrell (1966) have demonstrated that desert algae do show remarkable tolerance to salinity.

Jaines and Harper (1977) show that vascular plant cover in the deserts of southeastern Utah responds positively to sand content of soils and negatively to salinity: as noted above, cryptogamic species respond in a reverse fashion. Is it possible that both observa- 
Table 5. Average soil characteristics considered in the analysis of grazing effects on the development of cryptogamic crusts.

\begin{tabular}{|c|c|c|c|c|c|c|c|c|}
\hline Grazing treatment & $\begin{array}{l}\text { Rock } \\
\text { cover }(\%)\end{array}$ & $\%$ sand & $\frac{\text { Soil Texture }}{\% \text { silt }}$ & $\%$ clay & $\mathrm{pH}$ & $\begin{array}{l}\text { Cation } \\
\text { exchange } \\
\text { capacity } \\
\text { (meg/l00g) }\end{array}$ & $\underset{(\mathrm{mmhos} / \mathrm{cm})}{\mathrm{EC}}$ & $\begin{array}{l}\text { Extractable } \\
\mathrm{P}(\mathrm{ppm})\end{array}$ \\
\hline \multirow{3}{*}{$\begin{array}{l}\text { Average light } \\
\text { Average moderate- } \\
\text { heavy } \\
\text { i-valuc (light vcrsus } \\
\text { moderate-heavy }\end{array}$} & 41.9 & 55.3 & 32.2 & 12.5 & 8.6 & 9.7 & .17 & 21.5 \\
\hline & 37.8 & 54.3 & 32.8 & 12.9 & 8.7 & 10.0 & .17 & 20.4 \\
\hline & $.52^{n s_{1}}$ & $.52^{\mathrm{ns}_{1}}$ & $-.23^{\mathrm{ns}}$ & $-7.9^{\mathrm{ns}_{\mathrm{I}}}$ & $-1.23^{\mathrm{ns}_{1}}$ & $-1.18^{\mathrm{ns} \mathrm{s}_{1}}$ & $-.73^{\mathrm{ns}_{1}}$ & $1.60^{\mathrm{ns}_{1}}$ \\
\hline
\end{tabular}

${ }^{\text {ns }}$ Difference not significant at the .05 level.

tions can be correct? Hunt and Durrell's (1966) results in Death Valley tend to support the Utah data in that vascular plant cover was heavier on sandy soils than adjacent clays; also, they found cryptogamic species to remain important constituents of saline soils which are devoid of vascular plants. The success of algae on saline sites is undoubtedly related to physiological tolerance, but it also may be partially attributable to the near absence of vascular species which by virtue of larger size intercept a portion of the supply of two essentials of life for the photosynthetic cryptogams: precipitation and light.

There is increasing evidence that cryptogams both on and in desert soils exert a stabilizing influence against wind and water erosion. Our results indicate that the more obvious lichens and mosses, although primary stabilizers, are not as widespread nor as tolerant to grazing as are the filamentous algae. Careful examination of surface soils in deserts throughout the West will usefully reveal the presence of filaments of various species of blue-green algae. These observations suggest that primary emphasis should be placed on the filamentous, blue-green algae as schemes are evolved to consider cryptogamic plants in rehabilitating deteriorated rangelands, reducing erosion and assessing range conditions in arid zones.

Both cryptogamic cover and number of cryptogamic species are reduced by grazing. It thus seems feasible that if soil stability is enhanced even slightly by biologically induced crusts, the carrying capacity of many arid ranges must slowly but steadily decline through time so long as the grazing treatment precludes the reestablishment of some degree of cryptogamic crust. Kleiner and Harper (1972) have noted that vascular plant communities may appear well managed and healthy even while cryptogamic crusts are being severely disrupted. Managers of arid lands should be cautious about accepting sparse cryptogamic cover as natural.

Pragmatically, any domestic grazing use may prove to be incompatible with highly developed cryptogamic crusts such as those occurring in Virginia Park of Canyonlands National Park. We think it is possible, however, to manage grazing herds in such a way as to maintain filamentous algal growth on the surface of many, if not most semidesert ranges. Information such as optimum growth conditions for soil algae and when such conditions exist in the field are prerequisites to the implementation of sound grazing practices. Vigorous algal growth capable of controlling wind erosion during

Table 6. Number of cryptogamic species by life form encountered along 20 transects.

\begin{tabular}{lccccc}
\hline & \multicolumn{2}{c}{$\begin{array}{c}\text { Avg. no. species } \\
\text { per transect }\end{array}$} & & \multicolumn{2}{c}{$\begin{array}{c}\text { Total no. sp. } \\
\text { per treatment }\end{array}$} \\
\cline { 2 - 3 } \cline { 5 - 6 } Life form & Ungrazed & Grazed & & Ungrazed & Grazed \\
\hline Diatoms & 6.7 & 7.2 & & 15 & 29 \\
Filamentous algae & 1.9 & 1.9 & & 5 & 5 \\
Rock lichens & 3.8 & 3.2 & & 5 & 5 \\
Loose soil lichens & .8 & .9 & & 2 \\
Attached soil lichens & 3.3 & 1.5 & & 5 \\
Mosses & 1.2 & .2 & & 5 & 1 \\
Total species & 17.7 & 14.9 & & 36 & 47 \\
\hline
\end{tabular}

the dry season may be damaged more by late spring or year long grazing than winter grazing. Crust crushed during the dry season may not be able to support new algal growth to restabilize the fragile surface. At the present time, range scientists have inadequate data to answer such questions. We believe an effort should be made to gain such information.

From a management standpoint, there is no reason to suppose that encouragement of cryptogamic crusts through timing of grazing use will result in less vascular plant production. Kleiner and Harper (1972) observed that vascular plant cover does not seem to be suppressed by a heavy cover of cryptogamic crust. Likewise, in this study, vascular cover shows no significant differences between areas having heavy and light crusts. Any improvement in soil stability associated with more vigorous crusts would thus seem to be a bonus.

\section{Literature Cited}

Ali, S., and G.R. Sandu. 1972. Blue-green algae of the saline soils of the Punjab. Oikos 22:268-272.

Anantani, Y.S., and D.V. Marathe. 1974. Soil aggregating effects of some algae occurring in the soils of Kutch and Rajasthan. J. of Univ. of Bombay 41:94-100.

Anderson, D.C., and S.R. Rushforth. 1977. The cryptogamic flora of desert soil crusts in southern Utah. Nova Hedwigia 28:691-729.

Bischoff, H.W., and H.C. Bold. 1963. Phycological Studies. IV. Some soil algae from Enchanted Rock and related algal species. Univ. of Texas Pub. Publ. N. 6318.

Chapman, H.D. 1965. Cation exchange capacity. Methods of Soil Analysis. American Soc. of Agronomy, Inc., Publisher, Madison, Wisc., Part III:899-900.

Daubenmire, R. 1959. A canopy-coverage method of vegetational analysis. Northwest Sci. 33:43-64.

Day, P.R. 1965. Particle fractionation and particle size analysis. Methods of Soil Analyses. Amer. Soc. of Agronomy, Inc., Publisher, Madison, Wisc., Part I: 545-556.

Durrell, L.W., and L.M. Shields. 1961. Characteristics of soil algae relating to crust formation. Trans. Amer. Micro. Soc. 80:73-79.

Fletcher, J.E., and W.P. Martin. 1948. Some effects of algae and molds in the rain-crust of desert soils. Ecology 29:95-100.

Goldenburg, H., and A. Fernandez. 1966. Simplified method for the estimation of inorganic phosphorus in body fluids. Clinical Chem. 12:871875 .

Henriksson, E., and B. Simu. 1971. Nitrogen fixation by lichens. Oikos 22:119-121.

Holmgren, R.C. 1973. The Desert Experimental Range: description, history, and program, p. 18-22. In: D.N. Hyder (ed.), Arid Shrublands, proceedings of the Third Workshop of the United States/Australia Rangeland Panel. Soc. Range Manage., Denver.

Hunt, C.G., and L.W. Durrell. 1966. Distribution of fungi and algae, p. 55-66. In: D. B. Hunt, Plant Ecology of Death Valley, Califor. Geo. Surv. Prof. Pap. 509, U.S. Government Printing Office, Washington. 68 p.

Jaines, R.A., and K.T. Harper. 1977. The relative response of selected plant lifeforms to environment in southwest United States. Unpublished manuscript.

Kleiner, E.F., and K.T. Harper. 1972. Environment and community organization in grasslands of Canyonlands National Park. Ecology 53:229309.

Looman, J. 1964. Ecology of lichen and bryophyte communities in Saskatchewan. Ecology 45:481-491. 
Loope, W.L., and G.F. Gifford. 1972. Influence of a soil micro-floral crust on select property of soils under pinyon-juniper in southeastern Utah. J. Soil and Water Conserv. 27:164-167.

MacGregor, A.H., and D.E. Johnson. 1971. Capacity of desert algal crusts to fix atmospheric nitrogen. Soil Sci. Soc. of Amer. Proc. 35:843-844. Reddy, G.B., and J. Gibbons. 1975. Nitrogen fixation by algae on fescuegrass soil crusts. Soil Sci. Soc. Amer. 39:654-656.

Rychert, R.C., and J. Skujins. 1974. Nitrogen fixation by blue-green algaelichen crusts in the Great Basin Desert. Soil Sci. Soc. of Amer. Proc. 38:768-771.

Shields, L.M., and L.W. Durrell. 1964. Algae in relation to soil fertility. Bot. Rev. 30:92-128.
Shields, L.M., C. Mitchell, and F. Drouet. 1957. Algae and lichen stabilized surface crusts as soil nitrogen sources. Amer. J. of Bot. 44:489-498.

Singh, R.N. 1950. Reclamation of "Usar" lands in Indian through bluegreen algae. Nature (Lond) 165 (4191):325-326. (Feb. 1950).

Snyder, J.M., and L.H. Wullstein. 1973. The role of desert cryptogams in nitrogen fixation. Amer. Natur. 90:257-265.

St. Clair, L., and S.R. Rushforth. 1977. The diatom flora of Goshen warm springs ponds and wet meadow, Goshen, Utah. Nova Hedwigia 23:353425.

Steel, R.G.C., and J.H. Torrie. 1960. Principles and Procedures of Statistics. McGraw-Hill Book Co., Inc. New York.

Welsh, S.L., and G. Moore. 1973. Utah Plants. 3rd edition, BYU Press, Provo, Utah. 